\title{
PENGELOLAAN KONFLIK KOPERASI ELA LAYA DALAM KEMITRAAN DENGAN PERUSAHAAN SAWIT BESAR (PBS) DI KOTAWARINGIN TIMUR
}

\author{
Management Of Conflict In Cooperation Ela Laya In Partnership With The Big Palm \\ Company (PBS) In The East Kotawaringin
}

\section{Muhammad Yusuf* \\ Heriansyah}

Universitas Muhammadiyah Palangkaraya, Palangka Raya, Central Kalimantan, Indonesia

email:

yusuf.quratayun@gmail.com

Kata Kunci:
Pengelolaan
Konflik
Koperasi
Perusahaan Sawit Besar
Keywords:
Management
Conflict
Cooperative
Large palm oil Companies

\section{Accepted}

January 2019

Published

April 2019

\begin{abstract}
Abstrak
Koperasi Ela Laya didirikan pada tahun 2003 di Desa Barunang Miri dalam kemitraaan dengan salah satu Perusahaan Sawit besar di Kotawaringin Timur, namun eksistensi koperasi baru di akui tahun 2010. Selama 7(tujuh) tahun Koperasi Ela Laya melalui dinamika. Konflik yang terjadi diantara kedua belah pihak kerapkali menghambat kinerja koperasi dalam menjalankan fungsi dan tanggung jawabnya secara maksimal. Tujuan penelitian ini adalah mendeskripsikan pengelolaaan konflik Koperasi Ela Laya kemitraan dengan Perusahaan Sawit Besar di Kotawaringin Timur dengan pendekatan menghadapi konflik secara langsung.

Metode penelitian yang digunakan adalah deskriptif sampling dan data dianalisis secara induktif. Hasil penelitian menunjukan bahwa managemen konflik yang dilakukan koperasi membuahkan hasil setelah bertahun-tahun menghadapi konflik secara langsung. Dalam negosiasi dana mediasi, diperoleh kesepakatan-kespakatan baru yang menguntungkan kedua belah pihak dan masyarakat sekitar. Sebelumnya berbagai upaya yang dilakukan pengurus koperasi untuk mencapai titik tersebut melalui managemen konflik yang strategis. Upaya-upaya yang dilakukan antara lain persiapan intervensi meliputi mengubah pendekatan terhadap konflik dan mengurangi prasangka, memobilitasi massa untuk mendukung perubahan dengan melakukan hobi dan tindakan langsung anti kekerasan. Diperoleh juga informasi, ada upaya pengurus untuk mencegah konflik memanas dan tidak berubah menjadi kekerasan. Pengurus koperasi juga berupaya mempertahankan kehadiran dengan meminta perlindungan dan observasi tentang perkembangan situasi konflik di lapangan.
\end{abstract}

\begin{abstract}
The cooperative Ela Laya was established in 2003 in the village of Barunang Miri in Kemitraaan with one of the major palm oil companies in East Kotawartimur, but the existence of a new cooperative in the year 2010. For 7 (Seven) years Ela Laya's cooperative through the dynamics. Conflicts that occur between the two parties have hindered cooperative performance in carrying out its functions and responsibilities to the fullest. The purpose of this research is to describe the management of the conflicts Ela Laya partnership with the Big Palm Company in East Kotawartimur with a direct approach to conflict facing.

The research method used is descriptive sampling and the data is analyzed inductively. The results showed that the conflict management conducted by cooperatives resulted in the results after years of facing conflict directly. In the negotiation of mediation funds, obtained a new agreement that benefits both parties and the surrounding community. Previously, various efforts were made by cooperative managers to reach the point through strategic conflict management. Among other efforts, intervening interventions include changing approaches to conflict and reducing prejudice, to retract the masses to support changes by performing hobbies and direct anti-violent actions. Also obtained information, there is a caretaker effort to prevent conflicts to heat up and not turn violent. Cooperative managers also strive to maintain their presence by requesting protection and observation about the development of a field conflict situation.
\end{abstract}

\section{PENDAHULUAN}

Perkebunan kelapa sawit menjadi sumber konflik ketika ekspansinya bergitu besar di Indonesia dalam I4 tahun terakhir. Berdasarkan laporan WALHI (2014), dari tahun 2000 hingga tahun 2014 saja luas areal perkebunan sawit seluas 4,6 juta hektar menjadi 10.9 juta hektar. Ekspansi tersebut menjadi sumber konflik ketika pembangunan kerapkali kurang memperhatikan kepentingan masyarakat adat atau masyarakat lokal di sekitar pembangunan perkebunan kelapa sawit yang ditandai dengan perampasan tanah masyarakat, 
menggrogoti hutan yang menghilangkan keanekaragaman hayati hingga ketidakonsistenan perusahaan terhadap pendirian dan pemberdayaan koperasi.

Berdasarkan Peraturan Menteri Pertanian Nomor 98 Tahun 2013 tentang kemitraaan plasma sawit, bahwa perusahaan ini wajib untuk membangun kebun masyrakat sekitarnya, dimana areal lahan diperoleh $20 \%$ ijin lokasi perusahaan atau membangun kebun masyarakat yang ada di sekitarnya. Hal ini juga ditegaskan dalam ketentuan Indonesian Suistinable Palm Oil System (ISPO) yang bertuang dalam UU Nomor 39 Tahun 2014 tentang perkebunan yang mewajibkan perusahan mengikuti standar permbangunan kelapa sawit dengan memperhatikan faktor sosial, ekonomi dan lingkungan. Dalam hal ini pada faktor ekonomi, perusahaan wajib membangun kesejahteraaan dan ekonomi masyarkat dengan pembangunan perkebunan kelapa sawit yang kepemilikan lahannya oleh masyarakat.

Pembangunan perkebunan kelapa sawit di Kotawaringin Timur Provinsi Kalimantan Tengah cukup pesat namun kerapkali pembangunan perkebunan plasma masyarakat belum bisa dipastikan dan belum menjadi fokus, seperti yang tejadi di Desa Barunang Miri Kotawaringin Timur. Kondisi ini menjadi pemicu terjadinya konflik horizontal antara perusahaan seperti tidak terealisasinya pembangunan plasma seluas $20 \%$ dari lahan yang diusahakan inti, pola bagi hasil plafon kredit, ketersedian lahan terbatas dan kurangnnya komunikasi dengan masyarakat. Oleh karena itu pada tahun 2003 tokoh masyarakat di Desa Barunang Miri memulai usaha pendirian Koperasi Ela Laya kemitraaan dengan salah satu Perusahaan Besar di daerah setempat. Banyak hambatan yang ditemui tokoh masyarakat dan para pendiri dalam upaya pendirian Koperasi Ela Laya. Hingga atas kegigihan dalam menghadapi konflik yang efektif yang tepat pada tahun 2010 Koperasi Ela Laya baru diakui sebagai wadah bagi petani untuk meningkatkan kesejahteraan petani kemitraan dengan salah satu Perusahaan Besar Sawit (PBS) di Kotawaringin Timur.

Menurut Kreitner dan Kinicki (2010), konflik terjadi apabila seseorang atau unit mempunyai pandangan, keinginan dan persepsi yang tidak sama dengan seseorang atau unit lainnya. Fisher (200I) mengatakan bahwa apabila sebuah konflik tidak ditanggani dengan baik, maka konflik akan meningkatkan kemampuan individu, inovatif dan produktifitas kearah yang negatif sehingga merugikan orang lain.

Menurut Pruitt (198I) dalam Pole, Holmes dan Desanctis (1992) menegaskan bahwa untuk bisa melaksanakan manajemen konflik yang produktif, seorang pimpinan harus bisa mengabungkan faktor intergrative dan distibutive dalam interkasi penyelesaian konflik. Menururt Fisher, et al (200I) tidak ada tindakan atau strategi tunggal yang akan menghasilkan perdamaian. Perdamiaan dicapai melalui tanggung jawab bersama dan gabungan tindakan yang memunculkan perbedaaan yang sesunguhnya. Lingkaran strategi merupakan suatu cara untuk menyatukan semua alat analisis guna memilih strategi yang tepat dalam menyelesaikan konflik. Dalam lingkaran strategi beberapa kegiatan menunjukan serangkaian langkah dalam analisis konfli yang mungkin ingin kita coba. Adapu srategi manajemen konflik dengan lingkaran strategi adalah (I)Visi/ Sasaran; (2) perubahan yang diharapkan; (3)pihak-pihak yang terlibat; (4) identifikasi pihak-pihak yang terlibat; (5) Identifikasi isu-isu; (6)Identifikasi kepentingan; (7)Strategi; (8)Unsur yang terlibat; (9)Sekutu; ( I0)Risiko; (I I) Tindakan.

Koperasi adalah badan usaha yang beranggotaan orang, seseorang atau badan hukum. Setiap koperasi yang ada harus melandaskan seleuruh kegiatannya pada prinsip koperasi serta asas kekeluargaan untuk meningkatkan gerakan ekonomi rakyat. (Stoner, James A.., Managemen, 2nd ed, Prentice-Hall, 1982). 


\section{METODOLOGI}

Penelitian ini menggunakan rancangan kualitatif dekriptif. Penelitian kualitatif digunkan dengan pertimbngan fokus perhatian penelitian yaitu pengelolaan konflik koperasi Ela Laya dalam kemitraaan dengan Perusahaan Besar Sawit (PBS) di Kotawaringin Timur. Informan dalam penelitian ini menggunakan metode purposive sampling yang bertujuan untuk menggali informasi yang akan menjadi dasar dari rancangan dan teori yang muncul. Oleh karena itu informan di pilih benar benar kebutuhan peneliti selama pengumpuan data. Subyek penelitian terdiri dari (I) Unsur Pimpinan Koperasi Ela Laya; (2) Sekretaris (3) Anggota (4) Tokoh Masyarka yang terkait dengan penelitian ini. Data yang diperlukan selama penelitian adalah peristiwa-peristiwa (events), situasi (situasion) pada latar pelnelitian.

\section{HASIL DAN PEMBAHASAN}

Secara sosiologis konflik dipercaya memiliki 2 (dua) fungsi yakni fungsional dan tidak fungsional. Dalam pandangan struktural fungsional : (I) Konflik justru akan dapat menciptakan kreasi dan kemajuan masyarakat bahkan mampu mendewasaknnya (Hale,2003). Berdasarkan hasil penelitian, pengelolaan konflik Koperasi Ela Laya dengan PBS di Kotawaringin Timur adalah konflik laten yaitu konflik yang sifatnya sifatnya tersembunyi, oleh karena itu perlu diangkat ke permukaan sehingga bisa ditangani secara efektif.

Banyak sekali upaya yang dilakukan untuk menyelesaikan konflik. Hingga akhir Tahun 1980 an banyak terjadi peperangan antar negara. Namun sebagian besar perang sekarang adalah perang internal atau perang saudara misalnya pertikaian dalam negera sendiri seperti konflik antara masyarakat dan perusahaan sawit. Untuk membantu dalam mengelolah konflik maka harus dipahami terlebih dahulu sebab-sebab konflik.
Berdasarkan hasil penelitian, pengelolaan konflik Koperasi Ela Laya dalam kemitraan dengan PBS di Kotawaringin Timur disebabkan oleh masalah-masalah ketidaksetaraan dan ketidakadilan yang muncul sebagai masalah sosial, budaya,dan ekonomi yang disebut sebagai teori transformasi konflik. Oleh karena itu sasaran penyelesaian konflik adalah : (I) Mengubah berbagai struktur dan kerangka kerja yang menyebabkan ketidaksetaraan dan ketidakadilan termasuk kesenjangan ekonomi; (2) Meningkatkan jalinan hubungan dan sikap jangka panjang antara pihak Koperasi Ela Laya dengan PBS di Kotawaringin Timur; (3) Mengembangkan berbagai proses dan sistem untuk mempromosikan pemberdayaan, keadilan, perdamaian, rekonsiliasi dan pengakuan.

Sasaran penyelesaian konflik tersebut merupakan upaya mengelolah konflik secara langsung dengan pendekatan: (I) Persiapan intervensi, meliputi identifikasi dan mengubah pendekatan terhadap konflik; dan mengidentifikasi dan mengurangi prasangka; (2) Meningkatkan kesadaran dan mobilisasi untuk mendukung perubahan, melaui upaya lobi, kampanye dan tindakan langsung anti kekerasan; (3) Pencegahan yaitu mencegah konflik memanas sehingga berubah menjadi kekerasan; (4) Mempertahankan kehadiran, meliputi perlindungan tanpa senjata dan pematauan atau observasi; (5) Memungkinkan suatu penyelesaian yaitu membangkitkan kepercayaan, memfasilitasi dialog, negosiasi dan mediasi.

Konflik antara Pengurus Koperasi Ela Laya dan BPS di Kotawaringin Timur berlangsung laten dan lama, kurang lebih 7 (tujuh) tahun lamanya. Dalam menagemen konflik, pengurus Koperasi Ela Laya menggunakan pendekatan pemecahan masalah dengan cara menghadapi konflik secara langsung maka dapat dilihat sebagai berikut :

I. Persiapan Intervensi

Pada tahap ini pengurus Koperasi Ela Laya telah melakukan identifikasi dan mengubah pendekatan 
terhadap konflik dari pendekatan kompromistik ke pendekatan pemecahan masalah. Upaya lain adalah melakukan identifikasi presepsi dan mengurangi prasangka tentang koperasi dalam masyarkat. Dimana adanaya presepsi negatif dari masyarakat cenderung menimbulkan prasangka buruk tentang peran koperasi dalam kemitraaan dengan perusahaan. Upaya yang dilakukan pengurus koperasi untuk mengurangi prasangka adalah dengan melakukan dialog terhadap kelompok masyarakat yang merasa dirugikan karena oknum tertentu dalam koperasi.

Pengurus koperasi juga memberhentikan pengurus yang terindetifkasi melakukan kecurangan dalam koperasi. Selain itu pengurus koperasi berupaya melakukan pembuktian bahwa kehadiran koperasi di tengah-tengah masyarakat sebagai mitra dalam perusahaan semata-semata untuk mensejahterahkan masyarakat. Upaya yang dilakukan antara lain dengan memberikan bagi hasil yang sesuai dengan perjanjian koperasi terhadap anggota serta berperan aktif dalam upaya menyelesaikan konflik lahan antar sesama anggota.

2. Meningkatan Kesadaran dan Mobilitas untuk Mendukung Perubahan

Untuk mengingkatkan kesadarkan dan memobilisasi untuk mendukung perubahan, Koperasi Ela Laya melakukan berbagai macam cara seperti melobi dan tindakan langsung anti kekerasan. Lobi yang dilakukan oleh pengurus koperasi terbagi dalam 3 (tiga) kelompok sasaran yaitu kelompok masyarakat (sasaran utama), sasaran ke dua (Pemerintah Daerah, media dan LSM) dan sasaran ke tiga adalah Perguruan Tinggi. Lobi pada perguruan tnggi tidak terealisasi karena alasan jarak sehingga mengurungkan niat pengurus untuk melakukan komunikasi. Selain itu pengurus juga kurang memanfaatkan potensi media sebagai agent perubahan karena pengetahuan perngurus tentang media hanya terbatas pada publikasi berita saja bukan untuk advokasi dan perubahan.

Sedangkan tindak anti kekerasan yang dilakukan oleh pengurus koprasi meliputi protes dan aksi massa kepada perusahan dan ketidakpatuhan sipil terhadap aturan perusahaan. Sedangkan upaya "tidak mau berkerjasama" tidak dilakukan oleh pengurus karena koperasi telah melakukan kontrak kerjasama dengan pihak perusahaan yang memiliki badan hukum yang jelas sehinga apabila koperasi telah melakukan kontrak kerjasama dengan pihak perusahaan yang memiliki badan hukum yang jelas, sehingga apabila koperasi melanggar perjanjian kerjsama maka koperasi dapar berurusan dengan ranah hukum.

3. Pencegahan (Tindakan Mencegah Konflik Memanas)

Tindakan pencegahan sangat penting dilakukan untuk mencegah konlik yang memenas atau berkembang menjadi kekerasan. Pada tahap ini perungurs memberntuk tim khusus yang terdiri dari perwakilan anggota masyarakat, pemerintah daerah, dan elemen keamanan. Upaya yang dilakukan yaitu menginvestigasi insiden dan mencari tahu siapa yang terlibat, mengontrol rumor atau isu yang berkembang dalam masyarkat, melakukan dialog dengan melibatkan yang telah ditunjuk, meningkatkan solidaritas warga, mendorong rekonsiliasi, membuat kesepakatan dengan warga, menawarkan perbaikan atau ganti rugi kepada pihak-pihak yang merasa dirugikan serta merubah struktur koperasi yang membuat masalah atau merugikan.

4. Mempertahankan Kehadiran

Upaya pengurus koperasi untuk memmpertahankan kehadiran melalui metode perlindungan tanpa senjata yang dilakukan oleh LSM dana WALHI ketika konflik antar koperasi ela laya dna perusahaan intisawit serta pemantauan dan 
obsevasi untuk mengontrol perkembangan isu dalam masyarakat.

5. Upaya yang memungkinkan suatu penyelesaian Pada tahap ini koperasi berupaya untuk keluar dari konflik dengan melakukan beberapa pendekatan yaitu membangkitkan kepercayaan warga dengan mengurangi prasangka, negosiasi kembali dengan pihak perusahaan dan meminta mediasi pada saat negosiasi tidak berhasil. Dalam kegiatan negosiasi, koperasi berhasil meyakinkan perusahaan tentang eksistensi koperasi yang dapat menguntungkan perusahaan sehingga terbangun beberapa kesepakatan yaitu : (I) Perusahaan berkomitmen untuk tidak mengganggu managemen koperasi; (2) Perusahaan akan memberikan kesempatan kepada koperasi untuk perluasan usaha dalam bidang jasa pengangkutan hasil kebun ; serta (3) Perusahaan bersama koperasi akan membangun kesejahteranaan mamsyarakat sekitar dan berupaya meredam konflik yang ada dalam masyarakat. Melunaknya pihak perusahaan diduga karena implikasi dari merebaknya isu tentang revisi Undang-undang Nomor 18 Tahun 2004 tentang Perkebunan dan berdirinya perusahaan-perusahaan baru di Kecamatan Parenggean dalam bidang perkebunan sawit yang tentunya membutuhkan kemitraan koperasi sesuai dengan ketentuan undanng-undang.

\section{KESIMPULAN}

Berdasarkan hasil penelitian, pengelolaan konflik Koperasi Ela Laya dengan PBS di Kotawaringin Timur adalah konflik laten yaitu konflik yang sifatnya sifatnya tersembunyi, oleh karena itu perlu diangkat ke permukaan sehingga bisa ditangani secara efektif. Yang perlu dilakukan sebagai berikut :

I. Pengurus Koperasi Ela Laya hendaknnya memahami konflik secara komprehensif sehingga pendekatan yang diambil sangat strategis untuk segera menyelesaikan konflik antara koperasi dengan PT Surya Intisawit Kahuripan Sampit.

2. Pengurus Koperasi Ela Laya hendaknnya memaksimalkan potensi yang dimiliki oleh media dan perguruan tinggi sebagai ujung tombak perubahan dan advokasi kebijakan publik.

3. Melakukan Pendekatan penelitian tentang mengelolah berbagai dampak konflik sehingga dapat diperoleh evaluasi tentang hasil managemen konflik yang telah dilakukan.

\section{REFERENSI}

Chaerul, Anawar. 2014. Manjemen Konflik untuk menciptakan komunikasi yang efektif (studi Kasus di Departemen Purchasing PT Sumi Rubber Indonesia. Jurnal Interaksi,Vol.4 Nomor 2, Juli 2015.

Anstey, Mark. 1991. Negotiating Conflict: Insight and Skills for Negotiatiors and Paace Morkers. 157 Just Etco Ltd. Sounth Africa.

Augstburger, el.al. 1992. Mediation Across Cultures : Pattes and Pathways. Wetsinster/Know Press. London.

Bogdan, Taylor. 1992. Pengantar Penelitian Kualitatif. Usaha Nasional. Surabaya.

Bogdan, R,C,Biklen. 1992. Qualutative Research For Education : an Introduction to Theory and Methods. Allyn \& Bacon. Boston.

Burton, Jhon. 1990. Conflict Resolution and Prevention. Macmillan Shuster, Brookyale. London.

Cornelius,at al. 1989. Everyone Can Win : How to Solve Conflict. Simon. Australia.

Fisher, Simon, el.al. 200I. Mengolah Konflik, Keterampilan dan Strategi untuk Bertindak. The British Council Indonesia. Jakarta.

Poole,S.M, Holmes, M.,Desantics. 1990. Conflic Management in Computer Suported Meeting Enveroment. Mangemen Scienc,37 (8), 926-953

Stephen P.Robin. 1974. Managing Organizating Conflict. Hall Engle Clifts. Newyork.

Yuliani, Idris Jamaludin, Nasaruddin Usman. 2012. Manajemen Konflik Dalam Peningkatan Produktifitas Di Akademi Kebidanan Muhammadiyah Banda Aceh. Jurnal Administrasi Pendidikan, Pascasarjana Universitas Syiah Kuala Vol I, No.l Agustus 20l2) Hal 7-8I.

Zuldan Muhammad. 2012. Manajemen Konflik berbasis Komunitas Studi Kasus Community Oriented Policing (COP) di Malioboro Yogyakarta. Jurnal Ilmu Sosial 
dan Ilmu Politik Volume 17 No.2, November 2013 (Hal I30-143).

\section{Perundang-Undangan}

Undang-Undang Nomor 25 Tahun 1992 Tentang Perkoperasian

Undang-Undang Nomor 18 Tahun 2004 Tentang Perkebunan

Undang-Undang Nomor 17 Tahun 2012 Tentang Perkoperasian

Undang-Undang Nomor 39 Tahun 2014 Tentang Perkebunan

Peraturan Menteri Pertanian Nomor 33 Tahun 2006 Tentang Perngembangan Perkebunan Melalui Program Revitalisasi Perkebunan

Permentan RI Nomor 98 Tahun 2013 Tentang Pedoman Perizinan Usaha Perkebunan

Permentan RI Nomor 18 Tahun 2018 Tentang Pedoman Peremajaan Perkebunan Kelapa Sawit 